\title{
Assessment of the Chemical Composition in Different Dental Implant Types: An Analysis through EDX System
}

\author{
Fernando José Dias ${ }^{1}$, Ramón Fuentes ${ }^{1}{ }^{*}$, Pablo Navarro ${ }^{2}$, Benjamin Weber ${ }^{1}$ and \\ Eduardo Borie ${ }^{1}$ (D) \\ 1 Research Centre in Dental Sciences (CICO), Department of Integral Adults Dentistry, Dental School, \\ Universidad de La Frontera, Temuco 4811230, Chile; fernando.dias@ufrontera.cl (F.J.D.); \\ benjamin.weber@ufrontera.cl (B.W.); eduardo.borie@ufrontera.cl (E.B.) \\ 2 Universidad Autónoma de Chile, Temuco 4780000, Chile; pablo.navarro@ufrontera.cl \\ * Correspondence: ramon.fuentes@ufrontera.cl; Tel.: +56-452325775
}

Received: 19 July 2020; Accepted: 7 August 2020; Published: 14 September 2020

\begin{abstract}
The use of dental implants has been increasing in the last years; however, their chemical composition is an important issue due to the fact that the implant surface may suffer a corrosion process, allowing the possibility of ions being released and resulting in a possible biological response. Thus, the aim of this study was to evaluate the morphological analysis of the surface and chemical composition of different implant types through an energy-dispersive X-ray spectrometry (EDX) system. Eight dental implant models from different manufacturers were analyzed using variable pressure scanning electron microscopy (VP-SEM) and EDX. The chemical composition and general characteristics of the structural morphology in different dental implant surfaces were analyzed randomly. Nitrogen was identified in two samples, while zirconium was observed in only one model. Aluminium was identified in five samples ranging between $4 \%$ and $11 \%$ of its composition. Regarding the morphological characteristics, two samples from the same manufacturer had the most irregular surface designed to increase the contact surface, while the others revealed their surfaces with roughness at the micrometric level with no major irregularities. In conclusion, despite the morphology of implants being similar in most of the analyzed samples, more than $50 \%$ of them, which are brands of implants available on the market, showed aluminium on the implant surface. Finally, STR (Bone level, Roxolid), DENT (Superline) and NEO (Helix GM) could be considered, among the analyzed samples, the safest implants from the point of view that no aluminium was detected in their chemical composition.
\end{abstract}

Keywords: dental implants; biocompatible materials; spectrometry; X-ray emission; microscopy; electron; scanning

\section{Introduction}

The clinical indication and use of dental implants have been increasing in recent years [1,2], mainly due to improved knowledge and evidence associated with this treatment, the high level of patient satisfaction, its high success rate and the lower associated costs [3,4]. The success of treatment with dental implants depends on osseointegration [5], which has been defined as a direct and functional connection between a bone and an artificial implant. In this sense, the microscopic characteristics of dental implants, mainly chemical composition and surface treatment, can influence the osseointegration process [6].

The implant chemical composition is an important issue due to the fact that its external surface can be modified by environmental and mechanical factors [7]. It is common to find titanium and 
oxygen in the chemical composition of dental implants, observing in some cases even carbon, which are not considered as harmful elements [8-10]. However, there are several studies that reported other elements in the implant surface such as N, F, P, Cl, Na and some inorganic impurities as Al, Zn, Si, $\mathrm{Mg}$, among others [8-16]. These inorganic impurities of the implant surface may suffer a corrosion process [17], allowing ions releasing into the surrounding tissue [7], and in conjunction with their nature, it may result in a biological response that can be critical $[18,19]$ and the exposure to unknown risks $[15,20]$. Although the metabolism of implant surface ions is currently uncertain [20,21], some authors [20-23] have reported the release of aluminium and vanadium ions from the Ti-6Al-4V surface, found these in organs as the kidney, liver, brain and bone [22,24].

Some metals associated with alloys used in dental implants, such as $\mathrm{Cu}, \mathrm{Al}, \mathrm{Ag}, \mathrm{V}$ and $\mathrm{Mn}$, are associated with a high cytotoxicity and reduced cell viability [25]. Previous studies have demonstrated a possible relation between the $\mathrm{Al}$ concentration and neuronal apoptosis, even affecting memory and learning [26-28]. Aluminium has also been described as interfering in the bone remodelling process, [29] specifically inducing osteoblast apoptosis, and even reducing the parathyroid hormone levels [30].

The energy-dispersive X-ray spectroscopy (EDX) technique [31] has been widely used to analyse the elementary semi-quantitative composition of implant surface in different scenarios [8,10,11,15,16,32-35]. Although this method has proven to be practical and well accepted for this type of analysis, there is no consensus about the chemical compositions of dental implants and their surfaces. For example, different studies analyzed commercial pure titanium implants available in the market, reporting Ti concentrations ranging from $22.5 \%$ [9,14] to approximately $100 \%$ [10], but observing some impurities such as Fe [15], Al, Na and Si $[9,10,14]$.

It is fundamental that clinicians know the surface characteristics and chemical composition of implants that are currently available on the market and could be using, since it is the responsibility for the product that indicates and its possible effects on the health of patients. In this sense, there are doubts about the chemical composition and the trace components of the different commercial implant types available. Thus, the aim of this study was to evaluate the morphological analysis of the surface using variable-pressure scanning electron microscopy (VP-SEM) and the chemical composition of different implant types through an EDX system. The null hypothesis was that all the implants analyzed have similar morphological surface and chemical composition.

\section{Material and Methods}

\subsection{Surface Morphological Analysis of Dental Implants}

Eight dental implant models from different manufacturers were classified by cost $(<100$ USD and $>100$ USD) and then analyzed in this study. The implant models were summarized in Table 1. The dental implants analyzed were removed from its original packaging immediately prior to the three-dimensional surface analysis using VP-SEM (Hitachi SU3500, Tokyo, Japan). The implants were fixed on metal supports (stubs) with the aid of double-sided carbon tape. The increases in photomicrographs of X20, X100, and X300 were standardized, while in cases of specific regions of interest, images of X700 and X1000 were also obtained. Also, the general morphological characteristics, the roughness, and the defects on the surface of different implant models were described. 
Table 1. Characteristics of implant models used in the study.

\begin{tabular}{|c|c|c|c|c|c|c|c|}
\hline Implant & Manufacturer/Country & Size & Material & $\begin{array}{l}\text { Surface } \\
\text { Treatment }\end{array}$ & Ref. & Lot Number & $\begin{array}{l}\text { Cost } \\
\text { (USD) }\end{array}$ \\
\hline $\begin{array}{c}\mathrm{AB} \\
\text { (ARRP) }\end{array}$ & $\begin{array}{l}\text { Alpha-Bio Tec, Tel Aviv, } \\
\text { Israel }\end{array}$ & $3.0 \times 13 \mathrm{~mm}$ & Ti grade 5 & $\begin{array}{c}\mathrm{Al}_{2} \mathrm{O}_{3} \\
\text { sand-blasted/ } \\
\text { etched }\end{array}$ & 2423 & 1104109 & $<100$ \\
\hline $\begin{array}{l}\text { ANKI } \\
\text { (B17) }\end{array}$ & $\begin{array}{l}\text { Ankylos Friadent, } \\
\text { Mannheim, Germany }\end{array}$ & $4.5 \times 17 \mathrm{~mm}$ & Ti grade 2 & $\begin{array}{l}\mathrm{Al}_{2} \mathrm{O}_{3} \\
\text { sand-blasted/ } \\
\text { etched }\end{array}$ & 31010430 & B160003263 & $>100$ \\
\hline $\begin{array}{l}\text { ANKII } \\
\text { (B11) }\end{array}$ & $\begin{array}{c}\text { Ankylos C/X, Dentsply } \\
\text { Friadent, Mannheim, } \\
\text { Germany }\end{array}$ & $4.5 \times 11 \mathrm{~mm}$ & Ti grade 2 & $\begin{array}{l}\mathrm{Al}_{2} \mathrm{O}_{3} \\
\text { sand-blasted/ } \\
\text { etched }\end{array}$ & 31010050 & 013567 & $>100$ \\
\hline $\begin{array}{c}\text { DENT } \\
\text { (Superline) }\end{array}$ & Dentium, Seoul, Korea & $7.0 \times 7 \mathrm{~mm}$ & Ti grade 4 & $\begin{array}{l}\text { Sand-blasted/ } \\
\text { etched }\end{array}$ & FX7007SW & F10D02410 & $<100$ \\
\hline $\begin{array}{c}\text { LDRI } \\
\text { (Tixos MC) }\end{array}$ & Leader, Milano, Italy & $3.75 \times 10 \mathrm{~mm}$ & Ti grade 5 & ND (DLMF) & 09ITX3710 & E1014381 & $>100$ \\
\hline $\begin{array}{c}\text { LDRII } \\
\text { (Tixos MC) }\end{array}$ & Leader, Milano, Italy & $3.3 \times 10 \mathrm{~mm}$ & Ti grade 5 & ND (DLMF) & 09ITX3310 & E1114652 & $>100$ \\
\hline $\begin{array}{c}\text { NEO } \\
\text { (Helix GM } \\
\text { Acqua) }\end{array}$ & $\begin{array}{c}\text { Neodent, Curitiba, } \\
\text { Brazil }\end{array}$ & $3.75 \times 8 \mathrm{~mm}$ & Ti grade 4 & $\begin{array}{c}\mathrm{Al}_{2} \mathrm{O}_{3} \\
\text { sand-blasted/ } \\
\text { etched/ } \\
\text { immersed in } \\
\mathrm{NaCl} \\
\text { solution }\end{array}$ & 140.976 & 800341931 & $<100$ \\
\hline $\begin{array}{c}\text { STR } \\
\text { (Bone level, } \\
\text { Roxolid SLA) }\end{array}$ & $\begin{array}{l}\text { Straumann, Basel, } \\
\text { Switzerland }\end{array}$ & $4.1 \times 14 \mathrm{~mm}$ & $\mathrm{Ti}-\mathrm{Zr}$ & $\begin{array}{c}\mathrm{Al}_{2} \mathrm{O}_{3} \\
\text { sand-blasted/ } \\
\text { etched }\end{array}$ & 021.5514 & NN454 & $>100$ \\
\hline
\end{tabular}

\subsection{Chemical Analysis of Dental Implants}

The elementary semi-quantitative analysis of the different dental implants was performed with energy-dispersive X-ray spectrometry (EDX) using a 410-M detector (Bruker, Berlin, Germany) connected to the VP-SEM equipment. EDX is a technique that uses X-rays as a source of excitation for analyzing the chemical elements of different structures. This method is based on the principle that each chemical element has its own atomic structure, which allows a single peak of electromagnetic emission after its excitation [31]. One operator using nitrile gloves and a titanium forceps carefully removed the dental implants to be analyzed from its original packaging, so that there was no contamination on their surface. The implants were not washed or rinsed with any type of liquid so that there was no interference with the elements of cleaning. Then, the implants were then attached to the sample holder using double-sided carbon tape. Different areas of dental implants were analyzed randomly, in which the EDX system was set to detect automatically the element of surface, the data obtained represent the percentage of weight (wt.\%).

\section{Results}

\subsection{Surface Morphological Analysis of Dental Implants}

Most of the analyzed dental implants (AB, ANKI, ANKII, DENT), exhibited morphology consistent with their manufacture, with a standardized and well-defined structure, with minor differences in the morphology. The analyzed samples revealed a rough surface at micrometric level, with some irregularities or defects Figure 1. 

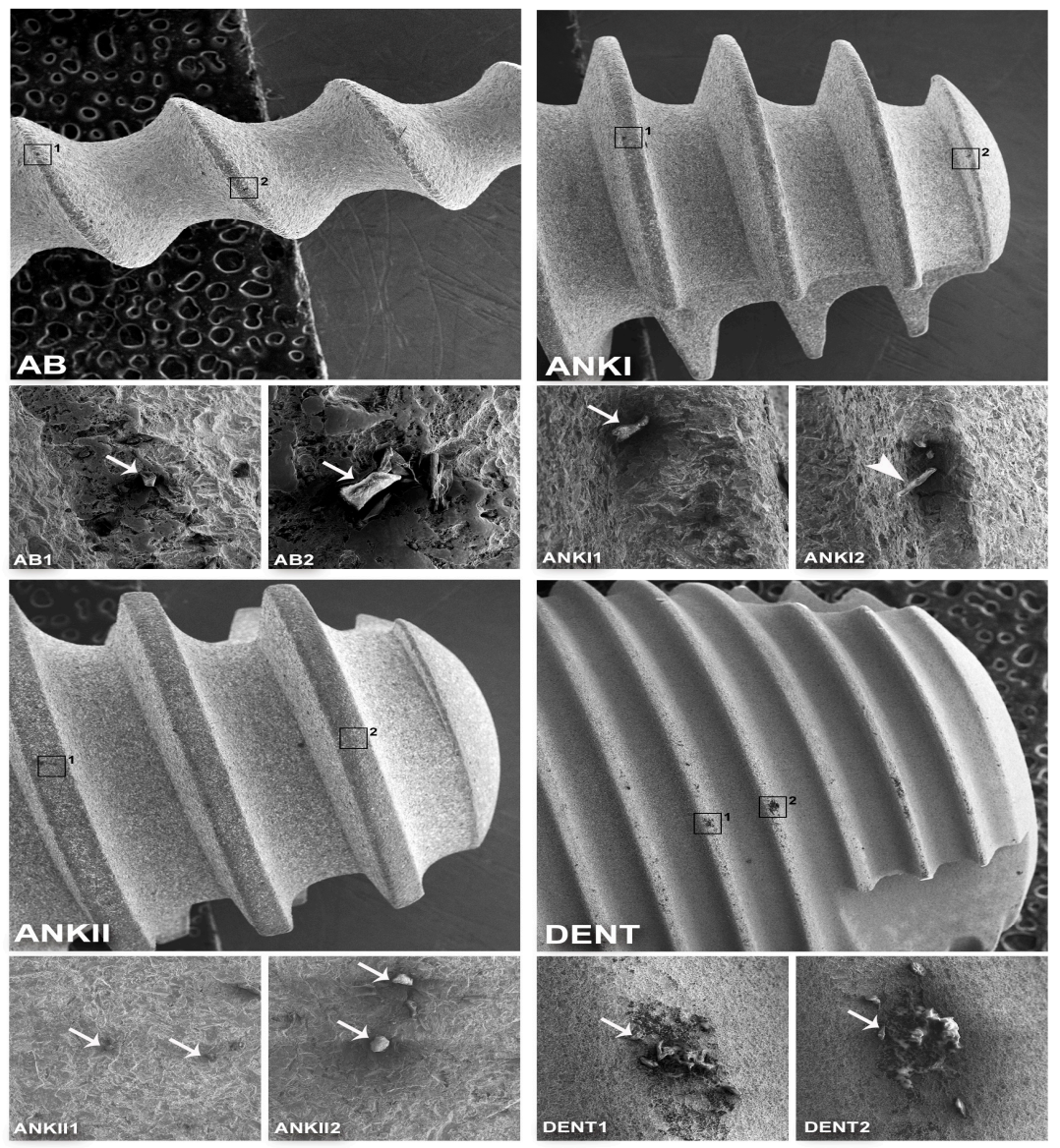

Figure 1. Three-dimensional structure of the Alpha-Bio, Ankylos (A11,B9.5), and Superline dental implants obtained by variable-pressure scanning electron microscopy (VP-SEM). (AB) General view of the Alpha-Bio implant structure (Mag: $\times 20)$. (AB1) Detail of the AB implant with a tip-shaped defect (arrow) (Mag: $\times 300)$. (AB2) At higher magnification another tip-shaped (arrow) defect is visualized (Mag: $\times 700)$. (ANKI) General view of the structure of the Ankylos A11 implant (Mag: $\times 20)$. (ANKI1) Detail of the ANKI implant surface with a tip-shaped defect (arrow) (Mag: $\times 300)$. (ANKI2) Detail of ANKI implant with defect in wire format (arrowhead) (Mag: $\times 300$ ). (ANKII) General view of the structure of the Ankylos B9.5 implant (Mag: $\times 20$ ). (ANKII1) Detail of the ANKII implant with small holes (arrows) (Mag: $\times 300)$. (ANKII2) Detail of the ANKII implant defect in spherical shape (arrows) (Mag: $\times 300)$. (DENT) Overview of the Superline implant (Mag: $\times 20)$. (DENT1) Detail of the surface of the DENT implant with an irregularly shaped defect with missing and excess material (arrow) (Mag: $\times 300)$. (DENT2) Detail of another irregular defect of the DENT implant that seems to adhere to the surface (arrow) (Mag: $\times 300)$.

The morphology of LDRI and LDRII samples diverged from the other samples due to their manufacturer's proposal characterized by a porous surface with interconnected pits and pores that tries to simulate the trabeculae of cancellous bone (Figure 2LDR). The NEO implant presented a different surface pattern due to the liquid in which it bathes that, when it dries is created an aggregate over the titanium surface (Figure 2NEO). The STR sample (Figure 2STR) showed a standardized and well-defined structure, but with a rougher surface compared to the AB, ANKI, ANKII, and DENT samples. Also, at greater magnification, it was noted that most of the samples (AB, ANK1, ANK2, DENT and NEO) revealed micro-irregularities on their surface, material deposits in the form of spheres, tips, or wires structures that seem to adhere to the implant surface Figures 1 and 2. 

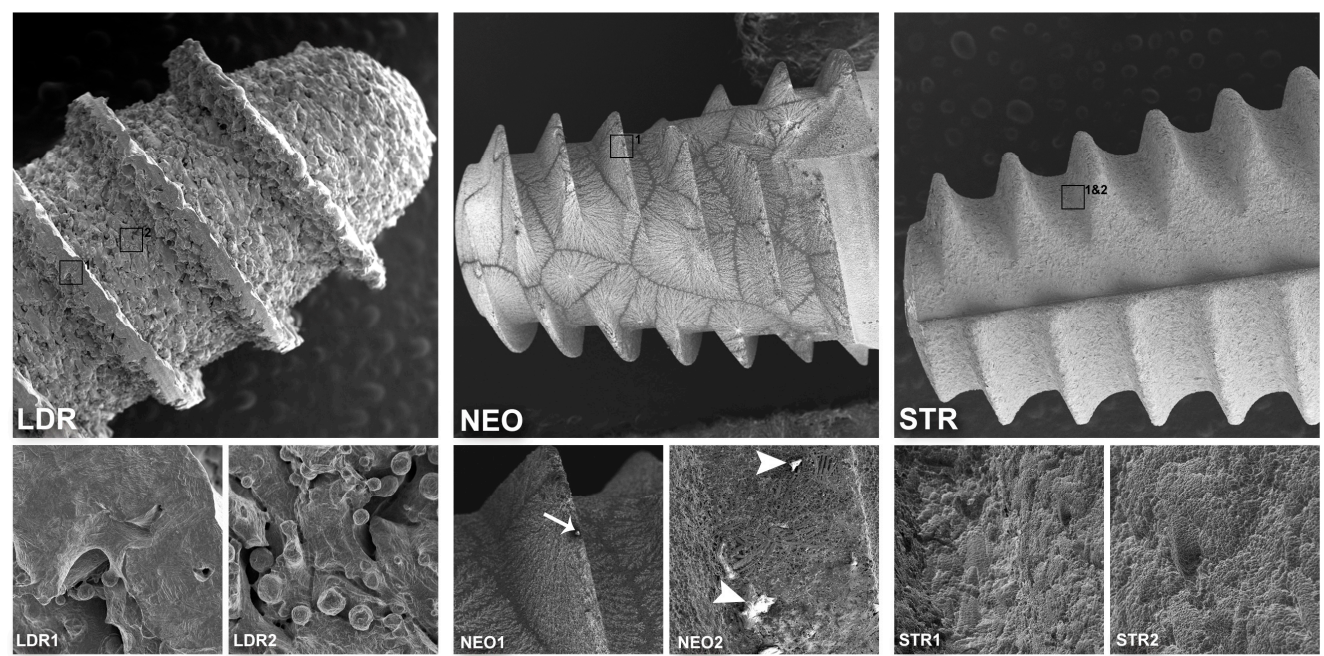

Figure 2. Three-dimensional structure of dental implants Tixos Leader, Neodent, and Straumann obtained by VP-SEM. (LDR) General view of the structure of the Tixos Leader implant (Mag: $\times 20$ ). (LDR1) Detail of the irregular surface of the LDR implant in the thread region (Mag: $\times 300)$. (LDR2) Detail of the irregular surface of the LDR implant with spherical recesses and elevations (Mag: $\times 300$ ). (NEO) General view of the structure of the Neodent implant (Mag: $\times 20)$. (NEO1) Detail of the NEO implant with the dried aggregate $(\mathrm{NaCl})$ on the surface and a defect in the form of elevation (arrow) (Mag: $\times 100)$. (NEO2) Detail of the surface characteristic of the NEO implant with the deposition of dry salt and some defects in different formats (arrowheads) (Mag: $\times 300$ ). (STR) General view of the structure of the Straumann implant (Mag: $\times 20$ ). (STR1) Detail of the STR implant surface with irregular topography (Mag: $\times 300)$. (STR2) In greater magnification, it is possible to observe the surface of the STR implant with irregular topography at the micrometric level (Mag: $\times 700$ ).

\subsection{Chemical Analysis of Dental Implants}

The chemical composition of the analyzed samples is summarized in Table 2. Sodium and Chlorine were identified only in the NEO sample, whereas zirconium (Zr) was observed only in the STR sample. Carbon (C) was detected in all samples with the exception of the DENT sample, while aluminium (Al) was identified in most of the samples, with the exception of DENT, NEO, or STR implants. Also, the weight percentage of titanium (wt. $\%$ ) in the different samples ranged from $67 \%$ to $100 \%$, identifying that only the DENT implant showed $100 \%$.

Table 2. Mean and standard deviation of weight percentage of chemical composition (wt.\%) in the different samples analyzed.

\begin{tabular}{cccccccc}
\hline Sample & $\mathbf{T i}$ & $\mathbf{O}$ & $\mathbf{C}$ & $\mathbf{A l}$ & $\mathbf{Z r}$ & $\mathbf{C l}$ & $\mathbf{N a}$ \\
\hline AB & $70.6 \pm 12.4$ & - & $24.5 \pm 12.8$ & $4.6 \pm 0.9$ & - & - & - \\
ANKI & $73.8 \pm 20.6$ & $24.7 \pm 0.4$ & $9.2 \pm 5.5$ & $6.5 \pm 0.5$ & - & - & - \\
ANKII & $67.1 \pm 0.1$ & $19.2 \pm 0.9$ & $4.2 \pm 3.8$ & $11.6 \pm 2.1$ & - & - & - \\
DENT & 100 & - & - & - & - & - & - \\
LDRI & $91.5 \pm 4.7$ & - & $4.6 \pm 0.6$ & $5 \pm 1.6$ & - & - & - \\
LDRII & $93.1 \pm 1.3$ & - & $2.5 \pm 0.3$ & $6.1 \pm 0.2$ & - & - & - \\
NEO & $92.9 \pm 4.1$ & - & $4.7 \pm 2.3$ & - & - & $1.2 \pm 0.04$ & $1.2 \pm 0.2$ \\
STR & $81.4 \pm 3.2$ & $5.6 \pm 0.7$ & $2.4 \pm 0.4$ & - & $13 \pm 0.4$ & - & - \\
\hline
\end{tabular}

\section{Discussion}

This study aimed to evaluate the morphological analysis of implant surfaces using VP-SEM and chemical composition of different implant types available in the market through an EDX system, to provide information to clinicians about their surface improvements and their composition, including new implant models, which would allow a better understanding about the products that 
dentists could be using. However, our data allow us to partially reject the originally stated hypothesis due to the similarities in the implant morphology between some analyzed samples. Most of the analyzed dental implants (AB, ANKI, ANKII, DENT), exhibited a standardized and well-defined structure, with minor differences in the morphology between them, identifying micropits, micro-roughness and large waviness, concurring with previous studies [14,36-39]. Also, morphological defects were identified in most of the samples evaluated; however, their reduced size and shape would not interfere in the osseointegration process of implants [40]. The STR sample showed a standardized and well-defined structure too, but with an apparent rougher surface compared to the AB, ANKI, ANKII, and DENT samples, which concurs with Smeets et al. [40] and Wennerberg and Albrektsson [41].

The surface morphology of LDRI and LDRII was the most irregular among the samples due to their manufacturer's proposal characterized by a porous surface with interconnected pits and pores that tries to simulate the trabeculae of cancellous bone [42]. LDR is a new implant made by additive manufacturing and with a very irregular surface, in which it would be interesting to evaluate the possibility of surface particle detachment during the implant insertion process, as was reported previously in other samples $[43,44]$. The NEO implant presented a different surface pattern due to the liquid in which it bathes that, when it dries, a salt aggregate is created over the titanium surface, which purpose is to augment its hydrophilicity with high surface energy, improving the osteoblast proliferation and increasing the osteogenic response [45].

All the samples analyzed showed a rough surface, in a greater or smaller scale, but which is an important factor that can influence the bone formation [46], increasing the wettability and, therefore, improving the protein absorption on the implant surface as well as the binding cells for bone ingrowth $[10,16,41,46]$. The rough surface is obtained by a surface modifications process that includes the anodization, titanium plasma spray, sandblasting with alumina, titanium or reabsorbable materials, and the etching with strong acids, among others [46,47]. Most of the samples analyzed, with exception of LDR, were subjected by the manufacturer to a technique associated with sandblasting with alumina particles $\left(\mathrm{Al}_{2} \mathrm{O}_{3}\right)$ and the particle removal through the immersion in a strong acid, due to this technique allows a larger contact surface when compared with others $[41,46]$. However, a recent study revealed remnants of particles in the implant's surface with a lack of process control in the particle's removal [16]. This issue, associated with the type of implant alloy, can influence the chemical composition of the implant surface. The titanium alloys depend on the grade and its purity, in which are found different percentages of oxygen, carbon, hydrogen, and titanium, highlighting that titanium alloy grade 5 has less titanium percentage and is associated with aluminium and vanadium on its composition [47].

The chemical composition of dental implants analyzed in this study showed that in most of the samples was the presence of carbon element (C) in ranges between 2-24\%, which was lower than observed in the other studies $13-48 \%$ using X-ray photoelectron spectroscopy and scanning electron microscopy (XPS/SEM) $[13,14]$. However, carbon is not considered as a harmful element and can be eliminated through Ar sputtering [13], which it should not be associated with possible contamination during the handling of the samples, due to the careful handling in unpacking the sample and its subsequent analysis. Regarding oxygen $(\mathrm{O})$, this was observed in the STR sample at approximately $5 \%$ and in the surface of ANK samples at a level of at least $19 \%$, which may be related to a possible form of titanium oxide on the implant surface $[9,13]$. It is often observed the presence of oxygen in the implant surface, being identified in higher ranges than observed in this study, achieving more than 50\% identified through (XPS/SEM) in some implant models [14]. In the case of ANK implants, the presence of oxygen by XPS/SEM on the implant surface was reported approximately at $49 \%$ by Dohan et al. [14], while Guler et al. [10], using EDX/SEM, found at approximately 36.8\%.

On the other hand, the zirconium element $(\mathrm{Zr})$ was observed only in the STR sample, explained by the Ti-Zr alloy used in this implant model, in a slightly smaller percentage (13\%) than the $15 \%$ reported by the manufacturer [48], which is considered as a safe and biocompatible element and with a low cytotoxicity similar to commercially pure titanium [25,49]. Elements such as zirconium, niobium, and tantalum are often added to titanium alloys to increase the strength due to their low toxicity $[25,50]$, 
which is the aim of the manufacturer in this sample. $\mathrm{Zr}$ was observed in a higher amount in this study when compared with previous researches, which were found in EDX/SEM analyses approximately $2 \%$ of $\mathrm{Zr}$ and some other inorganic impurities as aluminium and silicon [10,39]; however, there were no identified these elements in the sample analyzed in this study.

The low percentage of sodium $(\mathrm{Na})$ and chlorine $(\mathrm{Cl})$ identified only in the NEO sample is related to that implant is immersed in a $\mathrm{NaCl}$ solution. The surface treatment of this type of implant is similar to that of SLActive surfaces, which are sandblasted with alumina particles and etched with a strong acid, and then stored in a $\mathrm{NaCl}$ solution [39]. Thus, when the solution dries quickly it creates a $\mathrm{NaCl}$ aggregate over the entire surface, showing a similar behavior of SLActive surfaces [39,40,51].

ANKI, ANKII, LDRI, LDRII, and AB samples showed traces of aluminium ranging from $4 \%$ to $11 \%$, being more concentrated in the ANKII sample, which concurs with the researches of Dohan et al. $[9,14]$ who identified using XPS/SEM other inorganic pollution in the same samples. This finding is opposed by other authors $[10,16]$, who analyzed, using both analytical methods (XPS and EDX), the same implant model and did not detect aluminium particles. The presence of aluminium on the implant surface has been previously reported in several studies, regardless of the analytical method, observing a range between $1-14.4 \%[9,10,14,16]$, whose presence could be explained by the titanium alloy (Ti grade 5) used in the LDR samples, which includes aluminium in its composition, and, in the case of ANK samples, by the surface modification process of sandblasting with alumina particles, and possibly, by the incomplete particles removal during acid etching. However, some researches have been reported that alumina is an inorganic impurity insoluble in acid and difficult to remove from the titanium surface $[10,15]$. Also, in AB samples, either the sandblasting with alumina particles associated with an incomplete removal process or the titanium alloy (grade 5) used could explain the findings of aluminum on its surface. It is interesting that, despite NEO, STR, and DENT samples having the same surface treatment of sandblasting and then etched to remove the alumina particles, these samples did not show aluminium traces. Nevertheless, previous studies, using EDX and XPS methods, identified aluminium particles in STR samples $(1 \%)[10,14]$, while in the DENT sample was reported silicon (1\%) as a surface impurity [14].

The most important finding of this study is the high percentage found of aluminium in most of the analyzed samples, which can be critical given the current importance of the avoidance of the use of aluminium alloys, largely due to their possible relation to neurodegenerative diseases [52]. Specifically, aluminium is an element considered by some authors to be neurotoxic and neurodegenerative [23,52,53], involved in the deterioration of learning and memory [26]. Along with copper, they are considered the most cytotoxic metallic elements used in titanium alloys [25]. Zhang et al. [27,28] reported that even low exposure to aluminium has a toxic effects on the brain, mainly caused by severe oxidative deterioration of the neural cells. In the case of Ti-6Al-4V alloys, although a film of oxide protects the titanium surface, it can release aluminium ions after prolonged implantation [54], being identified both in blood plasma [17] as in the surrounding tissue [23]. Li et al. [22] studied the effect of aluminium nanoparticles on the immune system of mice using fluorescence imaging, reporting that these particles can introduce to the circulatory system and deregulate the immune system. It is important to highlight that even nontoxic concentrations of aluminium could be enough to produce biological changes since the tissue response depends on both nature and the amount of released ions [18].

The chemical composition of dental implants is an important issue due to the organic and inorganic contamination of commercial implants surface being reported [15]. In this sense, the clinical relevance of this contamination is unknown today, but possible local or adverse effects of the remnant particles as well the exposure to unknown risks may be discovered in the future. It is imperative that clinicians know the surface characteristics and chemical composition of implants that are currently available on the market since it is the responsibility of each dentist for the product indicated and its effects on the health of patients. Furthermore, it is necessary for manufacturers to improve their quality-control processes to avoid contaminants or unwanted substances in the composition of their products, which, even if in a small quantity, there are doubts about whether they could be detrimental to 
the health of patients. Thus, this research provides sufficient information about the surface morphology and chemical composition of some implant models that nowadays are available on the market and that dentists must know before their use or choose. Also, based on the implant's costs, there were no identified important differences among the samples, and it was observed that the chemical composition of the implant surface in the expensive implants was not necessarily free of impurities. Thus, the price was not correlated to implant surface pollution.

Within the limitations of this study is the number of implants analyzed, which was lower than similar studies [14] but higher than other research $[10,12,13,15]$. However, in this research, most implant models are different from these studies and the implants previously analyzed have some modifications on their surface. LDR is a new implant manufactured by direct laser metal forming (additive manufacturing) that try to simulate the trabecular bone with a different surface shape than the other samples and with no information about possible surface treatment, while the NEO sample is a new implant model too with a surface treatment similar to SLActive surfaces, but not previously studied.

It would be interesting to study the possible release of any ion to the surrounding tissue from analyzed dental implants, but it was not evaluated because it was not according to the aim of the study. However, further studies are necessary to study the biological mechanisms involved and the amount of ions that can be released from dental implants as well as the development of new materials and methods that improve the corrosion resistance of the implant surface and prevent the release of potentially dangerous ions [55].

It can be concluded that despite the morphology of implants being similar in most of the analyzed samples, more than $50 \%$ of them, which are implants models available on the market, have aluminium in their chemical composition that can be released into the peri-implant region and into the blood. The manufacturers should consider an adequate control during the manufacturing process to avoid further biological problems related to the potential risks of certain metallic ions. Finally, STR, DENT and NEO could be considered, among the analyzed samples, the safest implants from the point of view that no aluminium was detected on their chemical composition.

Author Contributions: Conceptualization, R.F. and B.W.; Formal Analysis, P.N., E.B. and R.F.; Investigation, F.J.D. and B.W.; Methodology, F.J.D. and P.N.; Project Administration, R.F. and E.B.; Writing-Original Draft, E.B., F.J.D., and B.W.; Writing-Review and Editing, E.B., R.F., B.W., P.N. and F.J.D. All authors have read and agreed to the published version of the manuscript.

Funding: Financed (partially, English editing) by Dirección de Investigación, Universidad de La Frontera.

Acknowledgments: The authors thank Karina Godoy from Scientific and Technological Bioresource Nucleus of Universidad de La Frontera (BIOREN-UFRO) for the technical support of EDX-SEM analysis.

Conflicts of Interest: The authors declare no conflict of interest.

\section{References}

1. Elani, H.W.; Starr, J.R.; Da Silva, J.D.; Gallucci, G.O. Trends in dental implant use in the U.S., 1999-2016, and projections to 2026. J. Dent. Res. 2018, 97, 1424-1430. [CrossRef]

2. Block, M.S. Dental implants: The last 100 Years. J. Oral Maxillofac. Surg. 2018, 76, 11-26. [CrossRef]

3. Mishra, S.K.; Chowdhary, R. Patient's oral health-related quality of life and satisfaction with implant supported overdentures-A systematic review. J. Oral Biol. Craniofac. Res. 2019, 9, 340-346. [CrossRef]

4. Muller, F.; Salem, K.; Barbezat, C.; Herrmann, F.R.; Schimmel, M. Knowledge and attitude of elderly persons towards dental implants. Gerodontology 2012, 29, e914-e923. [CrossRef]

5. Javed, F.; Ahmed, H.B.; Crespi, R.; Romanos, G.E. Role of primary stability for successful osseointegration of dental implants: Factors of influence and evaluation. Interv. Med. Appl. Sci. 2013, 5, 162-167. [CrossRef]

6. Giudice, A.; Bennardo, F.; Antonelli, A.; Barone, S.; Wagner, F.; Fortunato, L.; Traxler, H. Influence of clinician's skill on primary implant stability with conventional and piezoelectric preparation techniques: An ex-vivo study. J. Biol. Regul. Homeost. Agents 2020, 34, 739-745. 
7. Delgado-Ruiz, R.; Romanos, G. Potential causes of titanium particle and ion release in implant dentistry: A systematic review. Int. J. Mol. Sci. 2018, 19, 3585. [CrossRef]

8. Olefjord, I.; Hansson, S. Surface analysis of four dental implant systems. Int. J. Oral Maxillofac. Implant. 1993, 8, 32-40.

9. Dohan Ehrenfest, D.M.; Vazquez, L.; Park, Y.J.; Sammartino, G.; Bernard, J.P. Identification card and codification of the chemical and morphological characteristics of 14 dental implant surfaces. J. Oral. Implantol. 2011, 37, 525-542. [CrossRef]

10. Guler, B.; Uraz, A.; Cetiner, D. The chemical surface evaluation of black and white porous titanium granules and different commercial dental implants with energy-dispersive $\mathrm{x}$-ray spectroscopy analysis. Clin. Implant. Dent. Relat. Res. 2019, 21, 352-359. [CrossRef]

11. Klauber, C.; Lenz, L.J.; Henry, P.J. Oxide thickness and surface contamination of six endosseous dental implants determined by electron spectroscopy for chemical analysis: A preliminary report. Int. J. Oral. Maxillofac. Implant. 1990, 5, 264-271.

12. Massaro, C.; Rotolo, P.; De Riccardis, F.; Milella, E.; Napoli, A.; Wieland, M.; Textor, M.; Spencer, N.D.; Brunette, D.M. Comparative investigation of the surface properties of commercial titanium dental implants. Part I: Chemical composition. J. Mater. Sci. Mater. Med. 2002, 13, 535-548. [CrossRef]

13. Kang, B.S.; Sul, Y.T.; Oh, S.J.; Lee, H.J.; Albrektsson, T. XPS, AES and SEM analysis of recent dental implants. Acta Biomater. 2009, 5, 2222-2229. [CrossRef]

14. Dohan Ehrenfest, M.D.; Del Corso, M.; Kang, B.S.; Leclercq, P.; Mazor, Z.; Horowitz, R.A.; Shibli, H.L.W. Identification card and codification of the chemical and morphological characteristics of 62 dental implant surfaces. Part 3: Sand-blasted/acid-etched (SLA Type) and related surfaces (Group 2A, main subtractive process). POSEIDO 2014, 2, 37-55.

15. Duddeck, D.U.; Albrektsson, T.; Wennerberg, A.; Larsson, C.; Beuer, F. On the cleanliness of different oral implant systems: A pilot study. J. Clin. Med. 2019, 8, 1280. [CrossRef]

16. Schupbach, P.; Glauser, R.; Bauer, $\mathrm{S}$. $\mathrm{Al}_{2} \mathrm{O}_{3}$ particles on titanium dental implant systems following sandblasting and acid-etching process. Int. J. Biomater. 2019, 2019, 6318429. [CrossRef]

17. Jacobs, J.J.; Skipor, A.K.; Black, J.; Urban, R.; Galante, J.O. Release and excretion of metal in patients who have a total hip-replacement component made of titanium-base alloy. J. Bone Joint Surg. Am. Vol. 1991, 73, 1475-1486. [CrossRef]

18. Martin-Camean, A.; Jos, A.; Puerto, M.; Calleja, A.; Iglesias-Linares, A.; Solano, E.; Camean, A.M. In vivo determination of aluminum, cobalt, chromium, copper, nickel, titanium and vanadium in oral mucosa cells from orthodontic patients with mini-implants by Inductively coupled plasma-mass spectrometry (ICP-MS). J. Trace Elem. Med. Biol. 2015, 32, 13-20. [CrossRef]

19. Lutzner, J.; Gunther, K.P.; Postler, A.; Morlock, M. Metal ion release after hip and knee arthroplasty-Causes, biological effects and diagnostics. Z. Orthop. Unf. 2019. [CrossRef]

20. Costa, B.C.; Tokuhara, C.K.; Rocha, L.A.; Oliveira, R.C.; Lisboa-Filho, P.N.; Costa Pessoa, J. Vanadium ionic species from degradation of Ti-6Al-4V metallic implants: In vitro cytotoxicity and speciation evaluation. Mater. Sci. Eng. C Mater. Biol. Appl. 2019, 96, 730-739. [CrossRef]

21. Grenon, M.S.; Robledo, J.; Ibanez, J.C.; Sanchez, H.J. Titanium diffusion in shinbone of rats with osseointegrated implants. J. Microsc. 2016, 264, 182-188. [CrossRef]

22. Li, H.; Huang, T.; Wang, Y.; Pan, B.; Zhang, L.; Zhang, Q.; Niu, Q. Toxicity of alumina nanoparticles in the immune system of mice. Nanomedicine 2020, 15, 927-946. [CrossRef]

23. Chappard, D.; Bizot, P.; Mabilleau, G.; Hubert, L. Aluminum and bone: Review of new clinical circumstances associated with $\mathrm{Al}(3+)$ deposition in the calcified matrix of bone. Morphologie 2016, 100, 95-105. [CrossRef]

24. Goc, A. Biological activity of vanadium compounds. Cent. Eur. J. Biol. 2006, 1, 314-332. [CrossRef]

25. Park, Y.J.; Song, Y.H.; An, J.H.; Song, H.J.; Anusavice, K.J. Cytocompatibility of pure metals and experimental binary titanium alloys for implant materials. J. Dent. 2013, 41, 1251-1258. [CrossRef]

26. Niu, Q.; Yang, Y.; Zhang, Q.; Niu, P.; He, S.; Di Gioacchino, M.; Conti, P.; Boscolo, P. The relationship between Bcl-gene expression and learning and memory impairment in chronic aluminum-exposed rats. Neurotox. Res. 2007, 12, 163-169. [CrossRef]

27. Zhang, Q.L.; Boscolo, P.; Niu, P.Y.; Wang, F.; Shi, Y.T.; Zhang, L.; Wang, L.P.; Wang, J.; Di Gioacchino, M.; Conti, P.; et al. How do rat cortical cells cultured with aluminum die: Necrosis or apoptosis? Int. J. Immunopathol. Pharmacol. 2008, 21, 107-115. [CrossRef] 
28. Zhang, Q.L.; Li, M.Q.; Ji, J.W.; Gao, F.P.; Bai, R.; Chen, C.Y.; Wang, Z.W.; Zhang, C.; Niu, Q. In vivo toxicity of nano-alumina on mice neurobehavioral profiles and the potential mechanisms. Int. J. Immunopathol. Pharmacol. 2011, 24, 23S-29S.

29. Li, X.; Han, Y.; Guan, Y.; Zhang, L.; Bai, C.; Li, Y. Aluminum induces osteoblast apoptosis through the oxidative stress-mediated JNK signaling pathway. Biol. Trace Elem. Res. 2012, 150, 502-508. [CrossRef]

30. Diaz-Corte, C.; Fernandez-Martin, J.L.; Barreto, S.; Gomez, C.; Fernandez-Coto, T.; Braga, S.; Cannata, J.B. Effect of aluminium load on parathyroid hormone synthesis. Nephrol. Dial. Transplant. 2001, 16, 742-745. [CrossRef]

31. Goldstein, J.I.; Newbury, D.E.; Michael, J.R.; Ritchie, N.W.; Scott, J.H.J.; Joy, D.C. Scanning Electron Microscopy and X-Ray Microanalysis, 3rd ed.; Springer: New York, NY, USA, 2017; pp. 209-234.

32. Souza, F.A.; Queiroz, T.P.; Sonoda, C.K.; Okamoto, R.; Margonar, R.; Guastaldi, A.C.; Nishioka, R.S.; Garcia Junior, I.R. Histometric analysis and topographic characterization of $\mathrm{cp}$ Ti implants with surfaces modified by laser with and without silica deposition. J. Biomed. Mater. Res. B Appl. Biomater. 2014, 102, 1677-1688. [CrossRef]

33. He, X.; Reichl, F.X.; Wang, Y.; Michalke, B.; Milz, S.; Yang, Y.; Stolper, P.; Lindemaier, G.; Graw, M.; Hickel, R.; et al. Analysis of titanium and other metals in human jawbones with dental implants-A case series study. Dent. Mater. 2016, 32, 1042-1051. [CrossRef]

34. Beger, B.; Goetz, H.; Morlock, M.; Schiegnitz, E.; Al-Nawas, B. In vitro surface characteristics and impurity analysis of five different commercially available dental zirconia implants. Int. J. Implant. Dent. 2018, 4, 13. [CrossRef]

35. Souza, F.A.; Furtado, T.S.M.; Dayube, U.R.C.; Melo, W.M.; Nishioka, R.S.; Poli, P.P.; Maiorana, C.; de Carvalho, P.S.P. Comparative in vivo study of alloy titanium implants with two different surfaces: Biomechanical and SEM analysis. Clin. Oral Investig. 2019, 23, 4383-4397. [CrossRef]

36. Gehrke, S.A.; Perez-Diaz, L.; Mazon, P.; De Aza, P.N. Biomechanical effects of a new macrogeometry design of dental implants: An In Vitro Experimental Analysis. J. Funct. Biomater. 2019, 10, 47. [CrossRef]

37. Chang, J.Z.; Tsai, P.I.; Kuo, M.Y.; Sun, J.S.; Chen, S.Y.; Shen, H.H. Augmentation of DMLS biomimetic dental implants with weight-bearing strut to balance of biologic and mechanical demands: From bench to animal. Materials 2019, 12, 164. [CrossRef]

38. Juodzbalys, G.; Sapragoniene, M.; Wennerberg, A.; Baltrukonis, T. Titanium dental implant surface micromorphology optimization. J. Oral Implantol. 2007, 33, 177-185. [CrossRef]

39. Dohan Ehrenfest, M.D.; Del Corso, M.; Kang, B.S.; Leclercq, P.; Mazor, Z.; Horowitz, R.A.; Russe, P.; Oh, H.K.; Zou, D.R.; Shibli, J.A.; et al. Identification card and codification of the chemical and morphological characteristics of 62 dental implant surfaces. Part 5: Chemically coated surfaces (Group 3, coating) and implant collar surfaces (Group 4, collar). POSEIDO 2014, 2, 81-104.

40. Smeets, R.; Stadlinger, B.; Schwarz, F.; Beck-Broichsitter, B.; Jung, O.; Precht, C.; Kloss, F.; Grobe, A.; Heiland, M.; Ebker, T. Impact of dental implant surface modifications on osseointegration. BioMed. Res. Int. 2016, 2016, 6285620. [CrossRef]

41. Wennerberg, A.; Albrektsson, T. Effects of titanium surface topography on bone integration: A systematic review. Clin. Oral Implant. Res. 2009, 20 (Suppl. 4), 172-184. [CrossRef]

42. Leader Italia Implant Catalogue. Available online: http://partotasvir.com/catalogue/LEADER\%20Italia\% 20Implantology\%20Catalogue\%20\%20HD\%20version\%201.2.pdf (accessed on 11 July 2020).

43. Senna, P.; Antoninha Del Bel Cury, A.; Kates, S.; Meirelles, L. Surface damage on dental implants with release of loose particles after insertion into bone. Clin. Implant. Dent. Relat. Res. 2015, 17, 681-692. [CrossRef]

44. Deppe, H.; Wolff, C.; Bauer, F.; Ruthenberg, R.; Sculean, A.; Mucke, T. Dental implant surfaces after insertion in bone: An in vitro study in four commercial implant systems. Clin. Oral Investig. 2018, 22, 1593-1600. [CrossRef]

45. Gu, Y.X.; Du, J.; Si, M.S.; Mo, J.J.; Qiao, S.C.; Lai, H.C. The roles of PI3K/Akt signaling pathway in regulating MC3T3-E1 preosteoblast proliferation and differentiation on SLA and SLActive titanium surfaces. J. Biomed. Mater. Res. A 2013, 101, 748-754. [CrossRef]

46. Cicciu, M.; Fiorillo, L.; Herford, A.S.; Crimi, S.; Bianchi, A.; D’Amico, C.; Laino, L.; Cervino, G. Bioactive titanium surfaces: Interactions of eukaryotic and prokaryotic cells of nano devices applied to dental practice. Biomedicines 2019, 7, 12. [CrossRef]

47. Nicholson, J.W. Titanium alloys for dental implants: A review. Prosthesis 2020, 2, 100-116. [CrossRef] 
48. Straumann ${ }^{\circledR} \operatorname{Roxolid}^{\circledR}$. Available online: https://www.straumann.com/es/es/profesionales-de-laodontologia/ ciencia/bibliografia/roxolid.html (accessed on 10 May 2020).

49. He, X.; Reichl, F.X.; Milz, S.; Michalke, B.; Wu, X.; Sprecher, C.M.; Yang, Y.; Gahlert, M.; Rohling, S.; Kniha, H.; et al. Titanium and zirconium release from titanium- and zirconia implants in mini pig maxillae and their toxicity in vitro. Dent. Mater. 2020, 36, 402-412. [CrossRef]

50. Tardelli, J.D.; da Costa Valente, M.L.; de Oliveira, T.T.; dos Reis, A.C. Influence of chemical composition on cell viability on titanium surfaces: A systematic review. J. Prosthet. Dent. 2020, in press. [CrossRef]

51. Zinelis, S.; Silikas, N.; Thomas, A.; Syres, K.; Eliades, G. Surface characterization of SLActive dental implants. Eur. J. Esthet. Dent. 2012, 7, 72-92.

52. Nie, J. Exposure to aluminum in daily life and alzheimer's disease. In Neurotoxicity of Aluminum, Advances in Experimental Medicine and Biology, 1st ed.; Niu, Q., Ed.; Springer Nature: Singapore, 2018; pp. 99-111.

53. Gupta, V.B.; Anitha, S.; Hegde, M.L.; Zecca, L.; Garruto, R.M.; Ravid, R.; Shankar, S.K.; Stein, R.; Shanmugavelu, P.; Jagannatha Rao, K.S. Aluminium in Alzheimer's disease: Are we still at a crossroad? Cell. Mol. Life Sci. 2005, 62, 143-158. [CrossRef]

54. Okazaki, Y.; Gotoh, E. Comparison of metal release from various metallic biomaterials in vitro. Biomaterials 2005, 26, 11-21. [CrossRef]

55. Katic, J.; Šaric, A.; Despotovic, I.; Matijakovic, N.; Petkovic, M.; Petrovic, Z. Bioactive coating on titanium dental implants for improved anticorrosion protection: A combined experimental and theoretical study. Coatings 2019, 6, 612. [CrossRef]

(C) 2020 by the authors. Licensee MDPI, Basel, Switzerland. This article is an open access article distributed under the terms and conditions of the Creative Commons Attribution (CC BY) license (http://creativecommons.org/licenses/by/4.0/). 